\title{
Called and sent to make a difference: Radical missionality
}

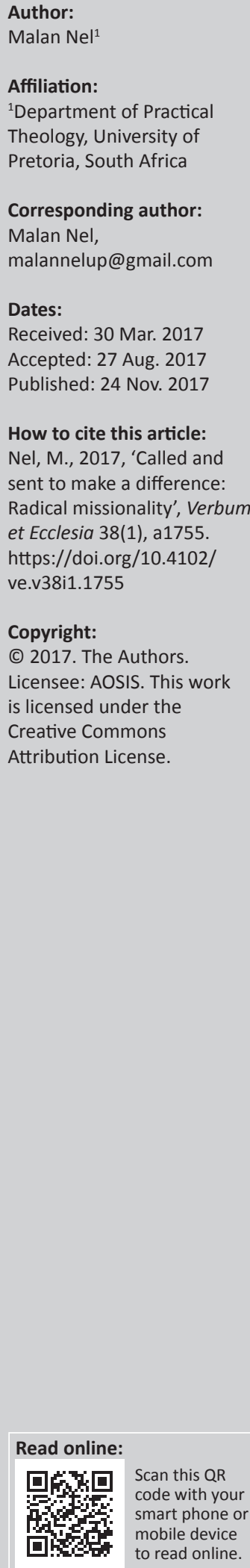

The concept 'missional' is well established within the so-called missional conversation. It is however often 'questioned' by scholars and pastors for different reasons. Sometimes it is almost dissected from the rest of theology, especially systematic theology. Recent developments in this field are given an account of in this article. The main purpose of the article is not to argue a case for the concept again. The purpose is to focus on whether theology and ministry in any way understand the radical implications if and when we are missional in being and doing. My assumption within the field of research on rediscovering discipleship in the development of missional congregations is that none of us have thought through how radical missionality is, especially over and against a 'volkskirchliche' understanding and practice of church. The article will also touch on some radical changes in philosophy of ministry and doing ministry within a missional paradigm.

Intradisciplinary and/or interdisciplinary implications: The article focuses mainly on Practical Theology and specifically Congregational Development ('Missionarische Gemeindeaufbau'). This field stands in a direct relationship with Missiology. The article contributes to a growing understanding of the radical nature of missional thinking and practice in congregational life and ministry.

\author{
Prayer of Confession \\ Lord God, we have given more weight to our successes \\ And our happiness than to your will. \\ We have eaten without a thought for the hungry. \\ We have spoken without an effort to understand others. \\ We have kept silent instead of telling the truth. \\ We have judged others, forgetful that you alone are judge and redeemer. \\ We have acted in accordance with our opinions \\ rather than according to your commands. \\ We have not been your faithful servants. \\ Forgive us. Have mercy on us. Redeem us. \\ Help us to live as disciples of Jesus Christ, \\ your Son, our Savior. Amen. (Nassau Presbyterian Church, Princeton, NJ, Bulletin, Sunday, January \\ $22,2017)$
}

\section{Introduction}

My reason for writing this contribution in English is because it is, in a sense, a follow-up on two articles already published (in English) as part of my current research interest, namely discipleship and its importance in developing a missional congregation and, as such, importance in youth ministry - the youth being an integral part of such a developing missional congregation.

The research questions I was and am challenged with are the following:

- My observation of whether within the missional conversation, discipleship (as often referred to) is comprehensively dealt with?

- My deep conviction that we are struggling to be a blessing to the world because we have confused (and even equated) confrontational evangelism and (with) disciplining.

- Whether we have shallowed the concept of discipleship, and with it membership, to become a culturally safe and comfortable experience of belonging to a community of the 'same'?

- Whether we are willing to be serious enough about the cost of discipleship, so much so that we do what the priority for disciples is - seeking the 'kingdom and his righteousness' (Mt 6:33) (NIV)? 
In this article, I will focus on the research question of whether we have shallowed the concept of discipleship and with it missionality, and with it the reality of membership, to become a culturally safe and comfortable belonging to a community of the 'same'? And, what would radical missionality entail? I have tried to argue a case in seeking some answers as to the first two questions in two previous articles and in my book (cf. Nel 2009a, 2015a, 2015b:186-201). The purpose of the article is therefore not to argue a case for everything that comes with an article on missionality as such.

\section{The essence of the problem}

Not many theologians differ about the theology behind the 'sentness' of the church. Bosch's monumental work (1991) has almost silenced the arguments that some may have come up with. Bosch (1991) and Newbigin (1995; cf. also Nikolajsen 2015:23-94 for a discussion of Newbigin's 'post-Christendom theology') were not the first to do so. In the Netherlands, for example, Hoekendijk (1966:15), who was so far ahead of his time, already argued for the same outcome. In South Africa, many scholars have written on the missional identity of the church, and for many years already (cf. e.g. Burger 1999; Hendriks 2004; Kganyapa \& Kgatla 2016; Niemandt 2010, 2016; Van Niekerk 2014).

We do differ, however, on the consequences of being sent. I argue that none of us who are working in this field have thought through and understand how radical missionality is. It sometimes seems like in the old days of the 'sending' mentality again: add a few help-giving programmes, add sending out a few more missionaries to wherever, as if programmes alone make us missional - or will help us 'buy off' our missional being. If we think and do in this way, we have once again tamed the concept, making it culturally and economically tame. Tame to the point that we can handle it, live with it and make it into something convenient. As if we think (again): God may dirty his hands, we will do the talking (cf. Nel 1994:130, 2007:98-117). Botman (2000:201-212) reflected, to my mind on this radical nature of discipleship in the South African context with his article on 'Discipleship and Practical Theology: The Case of South Africa. Towards a Practical Theology of Transformation' (cf. also Brueggemann 2013 and his discussion of the 'countercultural nature of Scripture').

Should we do so or continue to do so, the congregations miss out on, not only the real challenge but also the joy of being in mission as a mission. This is what congregational, contextual and missional 'satisfaction' is about, the cherry on the cake of being a missional congregation. Without this realisation of being changed into a new way of being and therefore doing, there is not much joy in being church. It is indeed about 'becoming the gospel' - to quote part of the title of Gorman's book (2015; cf. also Russell 2016:259-260; Kim 2016:361-362). Finding fulfilment in who we are and what we, because of that, do is the fruit of radical missionality. Erikson (1958:115, 123, 134-135, 178-179, 1964:132ff.; cf. also Luecke \& Southard 1986:14-15) referred to the fulfilment of a task as craftsmanship and as confirmation of identity. In this way, a sense of accomplishment is directly related to pastoral joy for all members alike.

There may be several reasons why there are sometimes (often?) 'negative reactions towards missional thinking and missionality as such':

- One reason may be that 'we' who try to think holistically about being church sense an one-sidedness in some of the approaches. It is as if the balance is not right. I (Nel 2015b:21) have referred to this balance, with reference to Roberts (1983:72-73) as follows: "This "being build up" is always consolidation and missionary at the same time and in this sense always missional.' I remember a day in a personal conversation with my then colleague, Prof A.B. $\mathrm{du}$ Toit, after a lecture where I used the terminology saying: One can never separate these two dimensions of being church in the New Testament. It may then be that some theologians, theological faculties and congregations feel that not enough attention is being given to 'consolidation', as Roberts has called it.

- A subconscious suspicion ré independentism may be another reason for a certain hesitation or negativity against missionality. Some missional thinkers are almost per se negative towards the current church and its structures. What Brennan (2007:13) wrote about the situation in the Roman Catholic Church as to working on the 'Refounding of the Church' (Arbuckle 1993) is true for many other denominations. There is still a tendency to be more 'about restorationism' than about, what I pleaded for, reformation and transformation of the congregation (cf. Nel 2015b:50-63). And while this is not what Brennan meant by using the term 'refounding', in the case of the well-respected Brian McLaren (cf. 2004:21, cf. also 2008) it did lead to the formation of an independent nondenominational congregation (cf. also Nel 2009b:2/17). McIntosh (2012:169-177) added as an appendix to his book There's hope for your church a chapter on Rebirthing a Church. He also, within the Church Growth movement, acknowledges the common statement by church planters, that it is so much 'easier to give birth than to raise the dead'. Easier to birth a new congregation than to resurrect 'dead' ones. He then continues to argue for rebirthing, but almost as an exception. Rice (2017), a consultant, wrote: 'My point is simple: we should stop sooner. A few congregations may dwindle down and still find a way forward, but most congregations, like most people, come to an inevitable end. At some point, most congregations die. What if, before that happens, we find a way to give the congregation's resources to someone else rather than hanging on until there is nothing left? What if we close when we can still celebrate rather than when we've been ground down by exhaustion and despair? What if we offer up everything we have as an opportunity for someone else's new life? Wouldn't that be a better, more faithful, more gracious way to think about closing?'

- While these last remarks are so relevant, it is the acceptance that small congregations will die and cannot 
be turned around to become missional; it is to my mind this 'easier to start new churches' that puts our emphasis on missionality under suspicion among some scholars and pastors. We are not open enough to work with a 'whatever it takes' to reform the current many 'declining' congregations into fully functioning missional and contextual faith communities.

- Reservations about the concept and issue at stake in missionality may also be because of a subconscious 'fear' for the radical consequences of missionality. Being transformed into a missional congregation may disturb the peace and may make 'us' lose members and donors. I will never forget his story. He was a young pastor in a small rural congregation. He never confirmed this with me, but this small church was probably run by a few families as is sometimes the case in smaller rural congregations. After he preached on a Sunday morning on reconciliation between people (in South Africa), he received a call - even before being back home. It was from a farmer saying how unhappy he was about the sermon and would like to see him. He visited the family that same week, and after learning what the unhappiness was about, he started explaining and referred to Scripture. After the third time referring to 'the Bible says', the farmer pointed his finger at him and said: 'This is the last time you use those words in my house. I do not want to know what the Bible says'. When people who are 'Gottentfremd', while not yet estranged from the church, fills the pews, pastors became -subconsciously afraid for the consequences of radical missionality - all over the world, but even more so in a country like ours, South Africa.

- A last possible reason, closely related to the previous, may be to make a final peace with the understanding that 'christendom' is over. Hoekendijk (1966:15) already argued against Christendom (cf. also 1948, 1952). When the death of Christendom goes with the loss of political power for 'us' in Afrikaans-speaking churches, saying goodbye is even more difficult. Boshoff (2012) has shown beyond a doubt that when congregations have not worked through (mourning) the trauma of losing the benefits of an apartheid-defined Christendom, it infringes heavily on the development of a missional congregation. When these losses affect, like in the case of the Afrikaansspeaking churches, even the language of the members the mourning process is hampered even more. Hamman's (2005:12-13) important distinction between grieving and mourning explains how, when we only grief, we are held captive to and by what we have lost. In Hamman's theory, he would encourage us to mourn, as 'mourning ... is the intentional process of letting go of relationships, dreams, and visions as your congregation lives into a new identity after the experience of lass and change'. Only when we do this might we discover that a missional future was (and is) in God's plan for the congregation all along. Hamman (2005:13) encourages congregations to: 'do the work of mourning [which] is not about replacement but describes a process of evoking memories of the past, discerning the impact of change on the present, envisioning a future, and then living into that new identity'. (For how Hamman relates this theory to the South African situation, see his description under a heading 'when steeples cry as autobiography' [2005:1418].)

\section{Being called is in itself radical}

The calling of the congregation is radical grace at it most beautiful. And to fail to understand this, has often proofed to be disastrous. Volf (2015) reminds us in no uncertain terms that not living out this invested grace may make 'us' a curse rather than a blessing:

As it travels in time and space, the Christian faith needs regular realignments with its own deeper truth; such realignments are termed reformations. Christians, too, and not just their convictions, will need to keep realigning themselves to the authentic versions of their faith; these realignments are termed renewals. I exhort us as Christians to reform and renew our faith so as to lead lives worthy of the calling to which we have been called (Eph 4:1). If we don't, the Christian faith may well turn out to be a curse to the world rather than a source of blessing-an embodiment of the fall into the temptation to live by bread alone rather than a means of resisting it, a faith insufferably selfrighteous and arrogantly imposing itself on others to control and subdue them, a source of strife over worldly goods rather than a wellspring of confident humility, creative generosity, and just peace. (p. 26)

Calling reminds us of that divine passive. God is the acting Actor. Being church is a 'because' affair. And this divine involvement makes the congregation special - a counter community, an alternative possibility for living life in communion with the One who called and with the other called ones or many. In a book on Truth Speaks to Power Brueggemann (2013) added as a subtitle: 'The countercultural nature of Scripture.' Called by and in the presence of the God of Scriptures nothing is really culturally comfortable and convenient.

Calling also reminds us constantly of 'our' intentional presence in this world. One would be able to tell the story of creation all over again: out of nothing humans were created to be with and for creation what the Creator planned for the creation to be. Within every context, as part of the whole, this brings a real awareness of being here with a purpose.

This, too often, has become common knowledge. Congregations should be reminded of this radical claim of God on our lives (cf. Nel \& Scholtz 2015). Behind our 'being here', is God. Who we are, we are because of Him. We are being determined and defined by whose we are (Burger 1999:136ff., 155ff.). In our Reformed understanding of Identity, God is central and so it should be (Nel 2015b:38-48; Wright 2010:28-30,149).

Our calling is what makes us persevere. To be called is to know that you cannot turn around. You may flee from calling, but will return. Being called is to discover how not to stop. Even though it may include your own conversion to begin to understand what grace is - like the 'conversion' of 
Jonah (Jnh 3). Guder (2000:97-141) called it the continuing conversion of the church - a continuing turning away from our man-made 'reductionisms'. The implication of missional theology is indeed the conversion of the church (Guder 2000:143). As he (Guder 2000:26) has stated it: 'Evangelizing churches are churches that are being evangelized. For the sake of its evangelistic vocation, the continuing conversion of the church is essential.' In the words of Newbigin (1989:227), 'I am suggesting that the only answer, the only hermeneutic of the gospel, is a congregation of men and women who believe it and live it.' This is indeed the radical essence of developing or building a missional congregation (cf. Nel 1994, 2015b).

This continuing conversion for pastors and congregations is not only radical but difficult. Staying within paradigms that we have managed to be comfortable with seems more convenient. Rodríguez (2012) devoted a book to writing up the several paradigms 'of the church's self-understanding of being the church and of mission'. Of special importance, here is his chapter on the Christendom paradigm, as it figures so obvious in the missional conversation (Rodríguez 2012:31-44).

\section{Missionality or being sent}

Guder can be called a father figure in the missional conversation. He edited the second book (1998) in the series published in the Gospel and Culture Network. This network began to meet regularly in 1987 - to 'explore the many ramifications of Newbigin's theological and missiological offensive' (Guder 2015:xii; cf. Nikolajsen 2015:23ff. again). Guder reflects (2015) on the fact that since:

1998 the term 'missional' has become a basic concept in the global missiological discourse. At the same time, the term took on a life of its own and soon became as much a cliché as a useful theological formulation. (p. xiii)

Guder (2015:xv), searching for a theological centre, says that he senses that such a developing centre is taking shape. 'But with the risk in mind, I offer for the consideration of my readers the possibility that the underlying theme of these diverse studies is "Trinitarian missiocentricity"' (cf. a review by Paas 2016:58-59 on this publication).

\section{A few core characteristics}

My attempt here is not so much to describe the core characteristics again. I have stated it above that I am not arguing a case for the missional identity of the church. Many have done that already and I have done so in 2015, where each of the following values or characteristics was discussed in some depth. Having said that, I find the five core values as noted by the Church of England's Mission and Public Affairs Council (2009:81-82) valuable and to the point.

Five values for missional churches:

- a missionary church is focused on God the Trinity

- a missionary church is incarnational
- a missionary church is transformational

- a missionary church makes disciples

- a missionary church is relational.

\section{At the heart}

At the heart of the matter lies our understanding of the church, our identity. 'I am absolutely convinced that understanding identity determines purpose. Identity comes before purpose.' This once was my answer in response to a question on the book of Warren (1995), The Purpose Driven Church. My reason for referring to this answer is not to suggest in any way that Warren does not see it this way too. My reason for sharing is to tell where the title Identity Driven Churches. Who Are We and Where Are We Going? comes from (Nel 2015b):

Does a title make it easier to understand missionality? No, not really. Identity is complex and hard to define, but when we develop missional congregations who will impact context in a radical way, we cannot escape this challenge. Zscheile (2012) openly stated: At the heart of the missional church conversation lies a challenge: to recover and deepen the church's Christian identity in a post-Christendom world in light of the triune God's mission in all of creation. (p. 1)

However complex a reality ecclesiological and contextual identity might be (and it is), one truth stands out: We belong to God. Even while we struggle to find words to express who we are, we confess whose we are and to whom we belong. Root (2010:55-68) even has a chapter on 'the death of identity' working with a thesis that we create identity and that the church in this sense, has a 'thin identity' (2010:65). My personal leaning is towards a Biblical departure point. I want to respect the predicament as to what identity is, but also want to stay faithful to a faith-determined confession of who we are because of God. Our very being and reason for being is caught up in and by God, the Creator who is present and at work in his creation. Dietrich Bonhoeffer once wrote: 'The church is nothing else but a sector of humanity where Christ is really taking form' (Quoted by Fowler 1991:155).

The work done by Wright (2010) is another good example how an understanding is growing that a changed or transformed church and an understanding of mission helps the church finds its God given place (again). Answering the question who and what are we here for?, he wrote (Wright 2010):

It is not so much the case that God has a mission for the church in the world, as that God has a church for his mission in the world. Mission was not made for the church; the church was made for mission - God's mission... Mission arises from the heart of God himself, and is communicated from his heart to ours. Mission is the global outreach of the global people of a global God. (p. 24; A quote from Stott 1992:335)

He continues:

So when I speak of mission, I am thinking of all that God is doing in his great purpose for the whole of creation and all that he calls us to do in cooperation with that purpose ... But when I speak of 
missions I am thinking of the multitude of activities that God's people can engage in, by means of which they participate in God's mission. (cf. also Newbigin [1953:xi] as quoted by Wright [2010:28])

God is present in his creation and especially so in humans, or as Moltmann (1985:15) said: 'God creates the world and at the same time, enters into it. He calls it into existence, and at the same time manifests himself through its being'. And in this world, we, however difficult to define, are 'a fellowship of differents: Showing the world God's design for life together', as McKnight (2015) titled his book.

The sending of the Son testifies to this presence of God: 'The mission of the Son means that God is present in the history of the whole of creation. He is for the world and its inhabitants' for all of those who lives in it (Pasztor 2001:140). The mission is God's and we participate in it, so much so that God's mission becomes the mission of the church.

\section{Important and radical consequences}

\section{Ecclesiological reformation}

Developing missional congregations can never escape radical reformation. It is my conviction that building up a missional local church is in essence a ministry of reformation (Nel 2015b:50-63). Whatever re- is put in front of whichever concept, this process is ultimately a process of reformation. This in itself is radical. Reformation has never been popular. Reformers are often, at least for a time, seen as heretics - like in the case of Luther. Many re-'s have been used to explain what is at stake. The most popular are: revival, renewal, revitalisation, rebirth, rekindling, reactivation and refounding.

Reformation is about rethinking, Biblically and contextually, who we are and how faithful we are to our calling. Mann (1998) said that:

no strategy, structure, or program will make much difference in the long-term viability of your church unless you go back to the fundamental question: How will we connect our deepest faithidentity to the realities of our context today? (p. 98)

\section{Gittins (2008) wrote:}

$[A]$ Church relying on imperial, hierarchical, patriarchal, sexist model that is unquestionably broken ... surely cannot be fixed, whether by fiat or fad, and certainly not by fission. Some things are beyond simple fixing; they must be radically restructured 'restored' in the truest sense of 'brought back into existence; brought back to health' (cf. also Nel 2015a:4/11). The remarks by Gittins (2008:185ff.) is critical: 'Would Jesus recognize the Church? What church would Jesus recognize?' (pp. 187-188)

Reflecting on missional ecclesiologies in creative tension as to the work of Niebuhr and Yoder, Park (2007:63) refers to the church as alternative community, 'in service of the universal community'. He then reflects on Yoder's understanding of the church as alternative community, defining the church as:

God's people gathered as a unit, as a people, gathered to do business in His name, to find what it means here and now to put into practice this different quality of life which is God's promise to them and to the world and their promise to God and service to the world. (Park 2007:69; Yoder 1971:30-31; cf. also Nielsen 2012)

Any theologian and pastor would know that reforming into this direction of being church is radical and expensive - it may cost you your popularity.

\section{Missional hermeneutic}

It may be necessary to state it one more time: I am not arguing a case for what belongs to missional theory. That will take me outside of my purpose in this article. This also applies to this section. Others have done so in excellent ways (cf., e.g. Flemming 2005, 2015; Gorman 2015). I do however want to briefly draw attention to this insight, an insight with, to my mind, a radical impact on our understanding of missionality.

Guder (cf. 2016:36) brought to the table that: (1) If mission is central in our understanding of God and his involvement with and in creation and (2) if the church does not have a mission, but are in mission, in God's mission, then it follows that the Bible was given to prepare the church, the people who know, love and serve God for its participation in the mission of God. Guder (2016:36) refers to this as one of the 'trajectories [that] may prove fruitful and transformative'. He then describes what I refer to here as: 'Developing and testing a missional hermeneutic that reads and interprets Scripture as the formation of communities of faithful witness in particular cultural contexts'.

God wants his people to fulfil their calling and his Word is their preparation for life, a life seeking the Kingdom of God and his righteousness, as Matthew (6:33) recorded Jesus saying. In the letter to the Ephesians, this is spelled out in even more detail. In my brief (Nel 2015b:13-21) Biblical exploration I have tried, with reference to several Old and New Testament sources, to point out that the concept 'building up' is missional in nature. The task at hand then is preparing (katartidzein) people for exactly this ministry: preparing everyone in the body or wall to be able to build into the wall those not yet in the body or wall (cf. Eph 4:1-16; cf. also Kok 2015 on the 'The radicality of early Christian oikodome').

The point is rightly so made that the whole of Scripture fulfilled this role in the early church. The letters were not just to comfort and console but to encourage and prepare for the missional task at hand. A beautiful example of this is Paul's reference to what one may call the total lifestyle of the Christian and being called to follow Paul as he follows the Christ:

31 So whether you eat or drink or whatever you do, do it all for the glory of God. 32 Do not cause anyone to stumble, whether Jews, Greeks or the church of God-33 even as I try to please everyone in every way. For I am not seeking my own good but the good of many, so that they may be saved. 1 Follow my example, as I follow the example of Christ. (1 Cor 10:31-11:1) 


\section{Rediscover the reason for being}

Osmer (1990) remarked as to the teaching office of the church:

Rediscovery is the activity of discerning once again the meaning and power of tradition that has been repressed or forgotten. Recovery goes further. It involves the positive evaluation and appropriation of that tradition, using what has been rediscovered to structure present patterns of thought and action. (p. 141)

In my description of this process in developing a missional congregation, I used the concept of 'unfreezing' (Nel 2015b: 223ff.) to describe the uneasiness that may go with this rediscovery and recovery. My attempt was and is to refer to the pain that often goes with the returning of life and emotions. When deformation is also because of plain and straightforward disobedience to God and his calling upon us, the conversion is also painful and shameful. Who will ever forget what two Afrikaans-speaking churches (NG Kerk 1986 and Ned Herv Kerk in 2015) went through when they had to admit and confess that apartheid was wrong and 'we' were wrong in supporting it. Realisation of wrongdoing is painful and shameful - so much so that many still today avoid the pain of admitting and confessing.

But this is what is at stake in missionality: because we are different, we do differently. We continually rediscover the reason(s) for our existence because of our God-given identity in Christ and through the Spirit. The sermon on the Mount is a great example of how Matthew packaged this: After 16 verses of who we are and what is true of us as a group of 'blessed' people - only then we are reminded of how different we behave in the presence of the King (cf. Mt 5:1-16 and followed by $5: 17-7: 29)$.

May I try to paraphrase the insights of McKnight (2015:1623) with regard to this radical difference in being and doing?:

God has designed the church - and this is the heart of Paul's mission - to be a fellowship of difference and differents. It is a mixture of people from all across the map and spectrums ... The church is God's world-changing social experiment of bringing unlikes and differents to the table to share life with one another as a new kind of family. When this happens, we show the world what love, justice, peace, reconciliation, and life together are designed by God to be. The church is God's show-and-tell for the world to see how God wants us to live as a family. (p. 16)

Because the local congregation is showing to its world how to understand the Christian life and because we are a 'fellowship of differents', the congregations represent:

- Different generations of men and women.

- Different socio-economic groups.

- Different cultures.

- Different musical styles.

- Different artistic styles.

- Different moral histories.

- Different forms of communication.

- Different marital statutes.

- We are called to admit that the Christian life is:

- a life in community with others

- a life being transformed
- a life with joy about differences

- a life of communion in love, justice and reconciliation (cf. McKnight 2015:16-17): 'To the degree that folks are invisible in our church, we don't have the right view of the church and the right view of the Christian life. In fact, the success of a church is first determined by how many invisible persons become visible to those not like them' (p. 20).

Mcknight then explores the most 'invisible' ones of this world and names the many unseen brokennesses, like in the case of the widow, child ('who are so often wall flowers'), young adult, senior, woman, Lesbian, Gay, Bisexual, Transgender, Questioning or Queer (LGBTQ) person and others:

The church is God's grand experiment, in which differents get connected, unlikes form a fellowship, and the formerly segregated are integrated. Those are to be one - not scattered all over the city - and they are one in Christ Jesus ... That thrashing it out is what the church is about - and that is what the Christian life is all about: learning to love one another, by the power of God's grace, so we can flourish as the people of God in this world. (McKnight 2015:23)

In summary of how different 'we' are, I quote McKnight (2015):

God loves us, and God's kind of love transforms us into loving and holy, God-glorifying and other-oriented people in God's kingdom. God's with-ness transcends simple presence and advocacy; his with-ness and for-ness are a transforming power ... The church God wants is one brimming with difference, and that will mean the Christian life is all about loving whoever happens to be with you in this fellowship of differents... The million-dollar question for you and me and how we do church is this:

How diverse is your love?

Or

How ready are you to love the differents in your fellowship?

To love everyone in or fellowship is a work of God's grace, the kind of grace that transforms us into a fellowship that welcomes and loves all. (Cf. also Schnelle 2009:114-121 for his discussion on the ethical radicalism of Jesus and the 'love command' as central in the ethics of Jesus). (pp. 59, 63)

\section{Contextually different and relevant}

A local congregation once wanted to erect a radio station, able to broadcast the gospel to people in Nairobi. When asked what they do where they are, the pastor paused for a long while and then shared that there was a 'squatter camp' (his words) across the street from their facilities and they do nothing there. I then asked: why then should people in Nairobi believe you? (cf. for the whole story Nel 2011).

The congregation is indeed God's gift to a very specific part of God's creation. For every local faith community, their 'world' is first of all their direct context. While individuals can make a difference on our behalf somewhere, maybe even 'far' away local faith communities as a whole can only make a difference here. Blauw (1962:43ff.) has said it then already: 'All the emphasis falls on the fact that the world of nations is a gift 
to the Messianic Servant; there is no reference here to the world as a "mission territory" of the Servant' (italics in original).

In South Africa (as all over the world) the context of local congregations is often challenging and very painful. Nowhere in the country can one escape the 'realities of injustice, oppression, poverty, discrimination, and violence' (Bosch 1991:10). We are only beginning to rediscover, like Bosch (1991:10) said then already, that mission is God's 'yes' and God's 'no' to and in this broken world: 'In our time, God's yes to the world reveals itself, to a large extend, in the church's missionary engagement in respect of the realities ...'

I do not know of any other place in this world where the temptation to escape contextual involvement may be more 'attractive' than in my own country. How do we get involvement in the reality of the 'squatter camp' across the street? Or in the down town or mid-city a few blocks from 'my' convenient home? And how do we discern how to do so as faith community and not only as individual with a 'handout' at the corner?

To be born again, to become flesh in our context is the radical challenge and very 'expensive' ministry venture. Guder (1998:11) wrote: 'There is but one way to be church and that is incarnationally'. In a later publication, he argued (Guder 1999):

What the world should experience in the church is not perfect Christians, but honest Christians whose life enflesh the real possibility of new life, a new creation, living hope, and confidence that "the one who began a good work among you will bring it to completion by the day of Jesus Christ. (Phil 1:6). (p. 23)

I will never forget a quote from Albert Schweitzer (without a reference) in the annual congregational calendar in the local church where we worship. Freely translated, it states: 'To be an example to others is not the main way of influencing others - it is the only way.'

This is indeed an obvious emphasis in literature within the missional conversation. In a book on five views in [this] conversation, Stetzer (2016:91-116) wrote on a view he calls $A n$ Evangelical Kingdom Community Approach. He summarises this view as:

God's people are to participate in the divine mission to manifest and advance God's kingdom on earth through the means of sharing and showing that gospel of the kingdom in Jesus Christ. (Stetzer 2016:92, italics in original)

Missional churches are not necessarily convenient. Being missional challenges barriers of discomfort. Where the Kingdom of God breaks through, people react differently. And God's mission is for a kingdom, and 'God's people have a Kingdom mission' (Stetzer 2016:99, 103). Warren's (2008: 61-73) contribution on Youth Ministry in an Inconvenient Church' reflects exactly on how challenging the call to discipleship and faithful missionality is. He compares live where consumerism is ruling and 'looking to the behaviors of Gospel practice' as faithfulness to the call of Christ and to recognise 'seeing others as the proxies of Jesus and as the locus of God's presence' (pp. 65, 71).

\section{Contextual implications}

What follows below are a few, to my mind radical implications, of being missional, especially so in my own reformed tradition. A continuing discovery of the meaning and implication of being missional asks of the church to be different:

- In our seriousness about God in Christ. This is and should in no way threaten our inclusivity but it does challenge our unique devotion and commitment to the Christ (cf. Root [2014] and his plea for an explicit Christopraxis; cf. also McDonald [2004:127-143]) and his mark for discipleship being 'A heart for Christ alone'. Guder (2016:27) stresses this to by referring to the Solas of the Reformation. To my mind, he justly states: 'Solus Christus (Christ alone!) is the overarching and undergirding conviction that shapes Reformation theology.'

- In our watchful jealousy, over our Reformed Identity.

- In our koinonial or relational being and our pastoral involvement with one another.

- In our concrete, earthly, Kingdom-like involvement in our communities and context.

- In our inclusivity, even if it hurts and irrespective of whether it hurts, like for instance in accepting the LGBTQ community.

- In our radical hospitality to the 'invisible' (McKnight 2015:20, 23) and the stranger.

- In our understanding of disciplining, learning together how to live life as we follow the Christ, as the only way of evangelising our neighbours.

I could add to this, many stories of congregations who are on this journey, not pretending to understand in full, but learning what it means as they discern how to be grateful for grace received - some would call this obedience because you love and are grateful!

Such stories can be found and read:

- Sjōgren (1993, 2002).

- Towers of Hope, Bloemfontein (http://www.towersofhope. $\operatorname{org} /)$.

- Central Presbyterian Church, Atlanta (https:/ / centraloac. org).

- North Avenue Presbyterian Church, Atlanta (www.napc. org).

- Ned Hervormde Congregation, Kempton Park-Oos.

- Pharos Community Centre, Lux Mundi Congregation (http://www.pharos.org.za/index.php/en/).

- $\operatorname{Nel}(2005)$.

\section{Conclusion}

This article is more of a confession than anything else: I do not know how radical missionality is. I do admit that I am trying to understand, while confessing that I do not know yet. There is integrity in us admitting and discovering as we discern what it might entail in a specific South African 
context, and hopefully share as we discover, as so many stories have been shared in the official weekly publication of the Dutch Reformed Church in the last 50 plus editions.

\section{Acknowledgements Competing interests}

The author declares that he has no financial or personal relationships which may have inappropriately influenced him in writing this article.

\section{References}

Arbuckle, G.A., 1993, Refounding the church: Dissent for leadership, Orbis Books, Maryknoll, NY.

Blauw, J., 1962, The missionary nature of the Church, Eerdmans, Grand Rapids, MI.

Bosch, D.J., 1991, Transforming mission. Paradigm shifts in theology of mission, Orbis Books, MaryKnoll, NY.

Boshoff, W.S., 2012, 'Gemeentes as begeleiers van kollektiewe rouprosesse', Verbum et Ecclesia 33(1), Art. \#726, 1-9. https://doi.org/10.4102/ve.v33i1.726

Botman, R.P., 2000, 'Discipleship and practical theology: The case of South Africa', IJPT 4, 201-212. https://doi.org/10.1515/ijpt.2000.4.2.201

Brennan, P.J., 2007, The mission driven Parish, Orbis Books, Maryknoll, NY

Brueggemann, W., 2013, Truth speaks to power. The countercultural nature of scripture, Westminster John Knox, Louisville, KY

Burger, C., 1999, Gemeentes in die kragveld van die Gees. Oor die unieke identiteit, taak en bediening van die kerk van Christus, BUVTON, Stellenbosch.

Church of England's Mission and Public Affairs Council, 2009, Mission-shaped Church Church planting and fresh expressions of church in a changing context, 2nd edn.,
Church House Publishing, London, pp. 81-82, First published 2004.

Erikson, E., 1958, Young man Luther, Norton, New York.

Erikson, E., 1964, Insight and responsibility, Norton, New York.

Flemming, D., 2005, Contextualization in the New Testament: Patterns for theology and mission, IVP Academic, Downers Grove, IL.

Flemming, D., 2015, Why mission?, J.B. Green (ed.), Series: Reframing New Testament Theology, Abingdon Press, Nashville, TN.

Fowler, J.W., 1991, Weaving the New Creation. Stages of faith and the public church, HarperCollins Publishers, San Francisco, CA.

Gittins, A.J., 2008, Called to be sent. Co-missioned as disciples today, Liguor Publications, Liguori, MO.

Gorman, M.J., 2015, Becoming the Gospel: Paul, participation, and mission, Eerdmans, Grand Rapids, MI.

Guder, D.L. (ed.), 1998, Missional church: A vision for the sending of the church in North America, Eerdmans, Grand Rapids, MI.

Guder, D.L., 1999, The incarnation and the church's witness, Trinity Press International Harrisburg, PA.

Guder, D.L., 2000, The continuing conversion of the church, Eerdmans, Grand Rapids, MI.

Guder, D.L., 2015, Called to witness. Doing missional theology, Eerdmans, Grand Rapids, MI, The Gospel and our Culture Series.

Guder, D.L., 2016, 'A multicultural and translational approach', in C. Ott (ed.), The mission of the church. Five views in conversation, pp. 21-39, Baker Academic Grand Rapids, MI.

Hamman, J.S., 2005, When steeples cry: Leading congregations through loss and change, Pilgrim Press, Cleveland, $\mathrm{OH}$

Hendriks, H.J., 2004, Studying congregations in Africa, LuxVerbi, Wellington.

Hoekendijk, J.C., 1948, Kerk en Volk in de Duitse Zendingswetenschap. Bydragen tot de Zendingswetenschap Part 1, Kampert \& Helm, Amsterdam.

Hoekendijk, J.C., 1952, 'The church in missionary thinking', The International Review of Missions XLI, 324-336. https://doi.org/10.1111/j.1758-6631.1952.tb03688.x

Hoekendijk, J.C., 1966, The church inside out, Westminster, Philadelphia, PA.

Kganyapa, L.T. \& Kgatla, T.S., 2016, 'Becoming a missional church: The struggle of the Lesotho Evangelical Church in Southern Africa or Paris Evangelical Missionary Society in Meadowlands, Soweto', HTS Teologiese Studies/Theological Studies Society in Meadowlands, Soweto', HTS Teologiese Stud
72(4), a3777. https://doi.org/10.4102/hts.v72i4.3777

Kim, K., 2015, Becoming the Gospel: Paul, participation, and mission, Eerdmans, Grand Rapids, MI, in M.J. Gorman, 2016, Theology 119(5), 361-362.

Kok, J., 2015, 'The radicality of early Christian oikodome: A theology that edifies insiders and outsiders', Verbum et Ecclesia 36(3), Art. \#1441, 1-12. https://doi. org/10.4102/ve.v36i3.1441

Luecke, D.S. \& Southard, S., 1986, Pastoral Administration. Integrating ministry and management in the church, Word Books, Waco, TX.

Mann, A., 1998, The in-between church: Navigating size transitions in congregations, Alban, Bethesda, MD.
McDonald, G., 2004, The disciple making church. From dry bones to spiritual vitality, Faith Walk Publishing, Grand Haven, MI.

McIntosh, G.L., 2012, There's hope for your church. First steps to restoring health and growth, Baker Books, Grand Rapids, MI.

Mcknight, S., 2015, A fellowship of differents: Showing the world God's design for life together, Zondervan, Grand Rapids, MI.

McLaren, B.D., 2004, A generous orthodoxy, Zondervan Emergent Youth Specialties, Grand Rapids, MI.

McLaren, B.D., 2008, Finding our way again: The return of the ancient practices, Thomas Nelson, Nashville, TN.

Moltmann, J., 1985, God in creation, Fortress Press, Minneapolis, MN.

Nel, M., 1994, 'Building up a missionary local church', in C.J.A. Vos (ed.), Proclaim the Gospel, pp. 130-148, Etiole, Pretoria.

Nel, M. (ed.), 2005, Stories van Hoop, CUM, Vereeniging.

Nel, M., 2007, 'Responsible evangelism in the presence of God: A theological reflection', PTSA 22(1), 98-117.

Nel, M., 2009a, 'Inviting and initiating youth into a life of discipleship', Verbum et Ecclesia 30(2), Art. \#344, 1-11. https://doi.org/10.4102/ve.v30i2.344

Nel, M., 2009b, 'Congregational analysis: A theological and ministerial approach', HTS Teologiese Studies/Theological Studies 65(1), Art. \#303, 1-17. https://doi. org $/ 10.4102 /$ hts.v65i1.303

Nel, M., 2011, 'Missionale integriteit en kontekstuele relevansie', HTS Teologiese Studies/Theological Studies 67(3), Art. \#1084, 1-9. https://doi.org/10.4102/hts. v67i3.1084

Nel, M., 2015a, 'Imagine-making disciples in youth ministry ... that will make disciples', HTS Teologiese Studies/Theological Studies 71(3), Art. \#2940, 1-11. https://doi. org/10.4102/hts.v71i3.2940

Nel, M., 2015b, Identity driven churches. Who are we and where are we going? BibleCor, Wellington.

Nel, M. \& Scholtz, E., 2015, 'Calling, is there anything special about it?', HTS Teologiese Studies/Theological Studies 72(4), a3183. https://doi.org/10.4102/hts.v72i4.3183

Newbigin, L., 1953, The household of God: Lectures on the nature of the church, London, SCM.

Newbigin, L., 1989, The Gospel in a Pluralist Society, Eerdmans, Grand Rapids, MI.

Newbigin, L., 1995, The open secret. An introduction to the theology of mission, rev. edn., Eerdmans, Grand Rapids, MI

Nielsen, A.Ø., 2012, 'Missional transformation. A constructive discussion applying the theologies of mission as transformation movement and Stanley Hauerwas', PhD dissertation, Faculty of Arts, Aarhus University, Aarhus, Denmark.

Niemandt, C.J.P., 2010, 'Five years of missional church. Reflections on missional ecclesiology', Missionalia 38, 397-412.

Niemandt, C.J.P., 2016, 'Rediscovering joy in costly and radical discipleship in mission' HTS Teologiese Studies/Theological Studies 72(4), a3831. https://doi.org/10.4102/ hts.v72i4.3831

Nikolajsen, J.B., 2015, The distinctive identity of the church. A constructive study of the Post-Christendom theologies of Leslie Newbigin and John Howard Yoder, PICKWICK Publications, Eugene, OR.

Osmer, R.R., 1990, A teachable spirit: Recovering the teaching office in the church, Westminster/John Knox, Louisville, KY.

Ott, C. (ed.), 2016, The mission of the church. Five views in conversation, Baker Academic, Grand Rapids, MI.

Paas, S., 2016, 'Review of Called to Witness', Soteria 33(1), 58-59.

Park, J.-S., 2007, Missional ecclesiologies in creative tension, Peter Lang, New York.

Pasztor, J., 2001, 'God's mission taken up as the mission of the church', in W. Brueggemann (ed.), Hope for the world. Mission in a Global context, pp. 137-149, Papers from the Campbell Seminar, Westminster John Knox Press, Louisville, KY.

Rice, S., 2017, When is the right time to close our doors?, Congregational Consulting Group, Alban Institute, viewed 27 February 2017, from http://www.alban.org

Roberts, J.H., 1983, Die brief aan die Efesiërs, NG Kerk Publishers, Kaapstad. (Also available in English).

Rodríguez, A., 2012, Paradigms of the church in mission. A historical survey of the church's self-understanding of being the church and of mission, WIPG \& STOCK, Eugene, OR.

Root, A., 2010. The promise of despair: The way of the cross as the way of the church Abingdon, Nashville, TN.

Root, A., 2014, Christopraxis. A practical theology of the cross, Fortress Press, Minneapolis, MN

Russell, A., 2015, Becoming the Gospel: Paul, participation, and mission, Eerdmans, Grand Rapids, MI, M.J. Gorman, 2016, Review \& Expositor 113(2), 259-260.

Schnelle, U., 2009, Theology of the New Testament, transl. M.E. Boring, Baker Academic, Grand Rapids, MI (Original Title: Theologie des Neuen Testaments, Vandenhoeck \& Ruprecht, Göttingen, 2007).

Sjōgren, S., 1993, Conspiracy of kindness, Vine Books, Ann Arbor, MI.

Sjōgren, S., 2002, The perfectly imperfect church: Redefining the 'ideal' Church, Flagship Church Resources, Loveland, MD.

Stetzer, E., 2016, 'An evangelical kingdom community approach', in C. Ott (ed.), The mission of the church. Five views in conversation, pp. 91-116, Baker Academic, Grand Rapids, MI. 
Stott, J., 1992, The contemporary Christian: An urgent plea for double listening, Intervarsity Press, Leicester.

Van Niekerk, A., 2014, 'The missional congregation in the South African context', HTS Teologiese Studies/Theological Studies 70(1), Art. \#2648, 6 pages. https://doi. org/10.4102/hts.v70i1.2648

Volf, M., 2015, Flourishing. Why we need religion in a globalized world, Yale University Press, New Haven, CT.

Warren, M., 2008, 'Youth ministry in an inconvenient church', in B.J. Mahan, M. Warren \& D.F. White (eds.), Awakening youth discipleship. Christian resistance in a consumer culture, pp. 61-73, Cascade Book, Eugene, OR.
Warren, R., 1995, The purpose driven church: Growth without compromising your message \& mission, Zondervan, Grand Rapids, MI.

Wright, C.J.H., 2010, The mission of God's people. A Biblical Theology of the Church's Mission, Zondervan, Grand Rapids, MI. (Series Biblical Theology for Life, General editor Jonathan Lunde.)

Yoder, J.H., 1971, The original revolution, Herald Press, Scottsdale, PA.

Zscheile, D.J., 2012, 'A missional theology of spiritual formation', in D.J. Zscheile (ed.) Cultivating sent communities. Missional spiritual formation, pp. 1-28, Eerdmans, Grand Rapids, MI. 